\title{
HUBUNGAN ANTARA IgM ANTI-CYTOMEGALOVIRUS (CMV), DNA CMV SALIVA DAN URIN PADA BAYI DENGAN MANIFESTASI KLINIS INFEKSI CMV KONGENITAL
}

\author{
Kasih Widhi Astuti ${ }^{\star 凶}$, Irene Ratridewi ${ }^{*}$, Dewi Santosaningsih ${ }^{\star *}$, Maria Inge Lusida***
}

\section{Abstrak}

Human cytomegalovirus merupakan penyebab utama infeksi kongenital di seluruh dunia. Infeksi kongenital cytomegalovirus (CMV) berkontribusi terhadap morbiditas, mortalitas, dan kualitas hidup bayi. Diagnosis tidak dapat ditegakkan berdasarkan klinis saja, namun diperlukan juga deteksi laboratoris. Penelitian ini untuk mengetahui hubungan manifestasi klinis infeksi CMV kongenital pada bayi dengan pemeriksaan serologi (IgM) dan pemeriksaan DNA CMV pada spesimen urin dan saliva. Penelitian crosssectional ini melibatkan bayi dengan gejala mengarah pada infeksi CMV. Pemeriksaan IgM anti-CMV dilakukan pada sampel darah dengan teknik $\mu$ capture dan DNA CMV pada sampel urin dan saliva diperiksa dengan metode PCR. Data dianalisis secara statistik menggunakan SPSS versi 22. Terdapat 32 pasien yang memenuhi kriteria inklusi. Didapatkan ikterus tidak behubungan dengan IgM anti-CMV $(p=0,228)$. Pneumonia dan necrotizing enterocolitis (NEC) berhubungan dengan IgM anti-CMV dengan nilai $p$ berturut-turut 0,002 dan 0,034. Manifestasi klinis CMV kongenital tidak berhubungan dengan DNA CMV urin maupun saliva. IgM anti-CMV berhubungan signifikan dengan DNA CMV urin $(p=0,002)$ dan DNA CMV saliva $(p=0,000)$. Sensitivitas pemeriksaan IgM anti-CMV terhadap DNA saliva dan urin berturut-turut sebesar $80 \%$ dan $75 \%$, sedangkan spesifitas $92,6 \%$ dan $89,3 \%$ pada bayi dengan manifestasi klinis infeksi kongenital. Dapat disimpulkan bahwa ikterus tidak berhubungan dengan IgM anti-CMV, sedangkan pneumonia dan NEC berhubungan dengan IgM anti-CMV. Manifestasi klinis CMV kongenital tidak berhubungan dengan DNA CMV pada bayi. Didapatkan IgM anti-CMV memiliki hubungan dengan DNA CMV. Dan didapatkan nilai sesnsitivitas, spesifisitas, nilai prediktif positif dan nilai prediktif negatif yang lebih rendah pada pemeriksaan IgM .

Kata kunci: DNA, IgM, manifestasi klinis CMV kongenital.

\section{THE RELATIONSHIP BETWEEN ANTI-CYTOMEGALOVIRUS (CMV) IgM, SALIVARY AND URINARY CMV DNA IN INFANTS WITH CLINICAL MANIFESTATIONS OF CONGENITAL CMV INFECTION}

\begin{abstract}
Human cytomegalovirus is a leading causes of congenital infections worldwide. Congenital cytomegalovirus (CMV) infection contributes to the infants' morbidity, mortality, and quality of life. The diagnosis cannot be based on clinical only, but laboratory detection is also required. This research is to determine the relationship between clinical manifestations of congenital CMV infection with a serological examination (IgM) and CMV DNA in urine and saliva specimens. This was a cross-sectional study that involved infants with CMV infection symptoms. Anti-CMV IgM examination was performed by $\mu$ capture method, while CMV DNA on urine and saliva was detected by PCR. Data were analyzed using SPSS version 22. There were thirty-two patients participated in this study. Jaundice was not related to Anti-CMV IgM $(p=0.228)$. Pneumonia and necrotizing enterocolitis (NEC) were related to anti-CMV IgM with $p$-value $=0.002$ and 0.034 , respectively. There were no relationships between clinical manifestations with CMV DNA. Anti-CMV IgM was related to urinary CMV DNA $(p=0.002)$ and also salivary CMV DNA $(p=0,000)$. The sensitivity of anti-CMV IgM compared to CMV DNA saliva and urine was $80 \%$ and $75 \%$, while the specificity was $92.6 \%$ and $89.3 \%$ in infants suspected with congenital infection. To conclude, icterus does not correlate with anti-CMV IgM, while pneumonia and NEC were correlated to anti-CMV IgM. Congenital CMV infection manifestations have no correlation with CMV DNA in infants. Anti-CMV IgM was correlated to CMV DNA. The values of sensitivity, specificity, positive predictive value, and negative predictive value were lower in the CMV IgM examination.
\end{abstract}

Keywords: DNA, IgM, clinical manifestations of congenital CMV.

* Departemen IImu Kesehatan Anak, Fakultas Kedokteran, Universitas Brawijaya

${ }^{* *}$ Departemen Mikrobiologi, Fakultas Kedokteran, Universitas Brawijaya

${ }^{* * \star}$ Institute Tropical Disease, Universitas Airlangga

E-mail: kasihwidhiastuti@yahoo.co.id 


\section{Pendahuluan}

Human cytomegalovirus (HCMV) merupakan penyebab utama infeksi kongenital di seluruh dunia yang mempunyai latensi seumur hidup. Infeksi kongenital cytomegalovirus (CMV) dapat berkontribusi terhadap morbiditas, mortalitas, dan kualitas hidup bayi berupa kecacatan neurologi nongenetik terutama gangguan pendengaran. ${ }^{1}$ Prevalensi infeksi CMV pada bayi secara umum sekitar $0,2-2 \%{ }^{2}$ Distribusi CMV terjadi di seluruh dunia terutama di negara berkembang dengan prevalensi sekitar 6-14\%.3 Transmisi virus pada CMV kongenital terjadi melalui transplasenta dan dapat terjadi pada tiap trimester kehamilan. ${ }^{1}$ Gejala klinis infeksi CMV pada wanita hamil tidak spesifik, dapat menyerupai flu-like syndrome dan $25-50 \%$ tidak bergejala.., 5

Manifestasi klinis infeksi CMV pada bayi meliputi berat badan lahir rendah (BBLR), prematuritas, kecil masa kehamilan (KMK), purpura atau ptekia, mikrosefali, ikterus, hepato -splenomegali, korioretinitis, kalsifikasi periventrikuler, dan gangguan pendengaran. Diagnosis infeksi CMV tidak dapat ditegakkan berdasarkan klinis saja, deteksi secara laboratoris diperlukan untuk menunjang diagnosis. ${ }^{6}$

Diagnosis pasti CMV pada bayi baru lahir dapat dilakukan bergantung pada ada tidaknya virus dari pemeriksaan isolasi virus melalui urin, identifikasi DNA CMV dengan pemeriksaan PCR (polymerase chain reaction) melalui urin, darah (termasuk darah kering), saliva dan cairan serebrospinal yang diambil dalam usia 3 minggu pertama pasca lahir, serta deteksi antigen atau $\operatorname{lgM}$ anti-CMV dalam darah. Spesimen saliva dan urin lebih direkomendasikan pada bayi karena didapatkan jumlah virus paling tinggi. 7,8 Pemeriksaan serologi mudah tersedia dan murah, meski tidak dapat diandalkan untuk diagnosis $\mathrm{CMV},{ }^{9}$ tetapi sangat membantu untuk menunjang diagnosis dini infeksi CMV kongenital di negara-negara dengan keterbatasan sarana. ${ }^{10}$ Adanya IgM yang positif saat lahir terduga kuat adanya infeksi CMV kongenital tetapi bila tidak ada, tidak menying- kirkan adanya infeksi CMV kongenital. Hal ini disebabkan oleh adanya imaturitas sistem imun pada neonatus. ${ }^{11}$

Pemeriksaan untuk menegakkan diagnosis pasti infeksi CMV tergolong mahal dan belum lazim dikerjakan di Indonesia. Selain itu, skrining terhadap bayi baru lahir terhadap infeksi CMV tidak dilakukan karena keterbatasan sarana dan biaya, sehingga mengakibatkan bayi dengan infeksi CMV tidak terdiagnosis. Meskipun gejala sisanya akan mempengaruhi kualitas hidup bayi di kemudian hari.

Penelitian ini bertujuan untuk mengetahui hubungan antara manifestasi klinis dengan pemeriksaan serologi lgM anti-CMV dan pemeriksaan DNA CMV pada saliva dan urin dengan menggunakan teknik PCR pada bayi baru lahir dengan berat lahir rendah dan atau kecil masa kehamilan yang merupakan salah satu manifesasi klinis infeksi CMV kongenital sehingga diagnosis pasti bisa ditegakkan.

\section{Bahan dan Metode}

Penelitian ini merupakan penelitian crosssectional dengan menggunakan rancangan studi observational analytic. Penelitian ini telah dinyatakan laik etik oleh Komisi Etik Penelitian Kesehatan RSUD. Dr. Saiful Anwar dengan nomor surat: 400/52/K.3/303/2018.

\section{Populasi dan Sampel}

Populasi penelitian ini adalah semua bayi yang dirawat di ruang perinatologi Laboratorium/SMF IImu Kesehatan Anak RSUD Dr. Saiful Anwar Malang. Subjek penelitian ini adalah pasien bayi dengan gejala mengarah pada infeksi CMV. Pengambilan sampel dilakukan secara consecutive sampling dengan kriteria inklusi: 1). Usia $\leq 3$ minggu, 2). Berat badan lahir rendah dan atau KMK, tanpa faktor risiko pada ibu, 3). Didapatkan salah satu dari manifestasi klinis dari infeksi CMV kongenital antara lain: mikrosefali, ikterus, trombositopenia, ptekiae atau purpura dan atau hepatosplenomegali. 
Adapun kriteria eksklusi yaitu: 1). Berat badan lahir rendah oleh karena gemelli, atau kelainan plasenta, 2). Trombositopenia oleh karena sepsis, kelainan trombosit pada ibu, 3). Ptekia atau purpura oleh karena kelainan faal hemostasis atau pembuluh darah, 4). Bayi telah mendapat transfusi darah, 5). Keluarga penderita tidak mengijinkan anaknya diikutsertakan dalam penelitian setelah diberikan penjelasan (informed consent).

\section{Preparasi Sampel Darah}

Sampel darah sebanyak $2 \mathrm{ml}$ dari setiap subjek diambil dengan pungsi vena perifer lalu dikirim ke laboratorium sentral RSUD Dr. Saiful Anwar Malang untuk pemeriksaan IgM anti-CMV.

\section{Pemeriksaan Serologi CMV}

Sampel darah sebanyak $2 \mathrm{cc}$ disentrifus pada 4000 rpm selama 15-20 menit kemudian digunakan untuk pemeriksaan serologi CMV dengan menggunakan mesin COBAS 411. Pemeriksaan IgM anti-CMV dilakukan dengan teknik $\mu$ capture.

\section{Preparasi Sampel Saliva}

Sampel saliva diambil dengan swab steril di mukosa pipi sisi dalam pada semua subjek penelitian, disimpan dalam tabung pada suhu $-20{ }^{\circ} \mathrm{C}$ kemudian dikirimkan ke laboratorium Institute Tropical Disease Universitas Airlangga untuk pemeriksaan DNA CMV dengan metode PCR.

\section{Preparasi Sampel Urin}

Pengambilan sampel urin sebanyak 5$10 \mathrm{cc}$ dilakukan menggunakan urine collector, urine disimpan dengan suhu $4{ }^{\circ} \mathrm{C}$. Sampel kemudian dikirim ke laboratorium Institute Tropical Disease Universitas Airlangga untuk pemeriksaan DNA CMV dengan metode PCR.

\footnotetext{
Pemeriksaan DNA CMV dengan Metode PCR

Pemeriksaan DNA CMV dengan PCR merupakan gold standard diagnosis CMV.
}

Pada saliva kering ditambahkan $300 \mu$ phosphat buffer saline (PBS). Selanjutnya, dimasukkan ke dalam tabung, divortex dan diinkubasi selama 20 menit dalam suhu kamar. Kemudian, 5 uL cairan yang mengandung saliva dilakukan isolasi DNA dengan menggunakan isolation DNA kit dengan merk Intron. Sedangkan sampel urin disentrifus pada 1500 rpm selama 20 menit. Supernatan dibuang, pellet dicuci dengan cairan PBS sebanyak $3 x$, kemudian dilakukan isolasi DNA dengan menggunakan isolation DNA kit dengan merk Intron. Amplifikasi DNA CMV menggunakan metode PCR kualitatif dengan primer oligonukleotida A1 (forward) 5' TATACCCAGACGGAAGAGAAA-TTCA-3' dan p r i m e r A 2 ( reverese): 5'ATAAGCCATAATCTCATCAGGGGAG -3'

\section{Analisis Statistik}

Data pada penelitian ini dianalisis menggunakan Statistical Package for the Social Sciences (SPSS) dari IBM untuk Windows, seri ke-22. Data disajikan dalam bentuk tabel distribusi frekuensi. Uji yang digunakan adalah: 1). Uji asumsi data, dengan normalitas dan homogenitas data pada data sampel untuk menentukan jenis analisis yang tepat digunakan selanjutnya, dengan menggunakan uji normalitas Saphiro Wilk, karena jumlah sampel kurang dari 50 , serta uji homogenitas Levene, 2). Uji korelasi, digunakan uji Chi Square, 3). Sensitivitas, spesifitas, positif predictive value dan negative predictive value pemeriksaan IgM anti-CMV terhadap pemeriksaan CMV dilakukan dengan uji Mc Nemar. Penelitian ini bermakna jika nilai $p<0,05$.

\section{Hasil}

\section{Karakteristik Sampel Penelitian}

Didapatkan 32 pasien yang masuk dalam kriteria inklusi dan kriteria eksklusi. Karakteristik dasar sampel penelitian yang diamati meliputi jenis kelamin, berat badan lahir, usia kehamilan, dan cara persalinan (Tabel 1). 
Hasil pemeriksaan $\operatorname{lgM}$ anti-CMV ditemukan 6 pasien (19\%) terdeteksi IgM antiCMV positif, sedangkan hasil pemeriksaan DNA CMV menunjukkan 5 (16\%) pasien terdeteksi DNA CMV pada spesimen saliva dan $4(13 \%)$ pasien terdeteksi DNA CMV pada spesimen urin. Sejumlah $4(13 \%)$ pasien terdeteksi DNA CMV baik pada spesimen saliva maupun spesimen urin.

Hubungan Manifestasi Klinis dengan IgM Anti -CMV pada Bayi Baru Lahir dengan Dugaan Infeksi CMV Kongenital

Ikterus tidak memiliki hubungan yang signifikan dengan lgM anti-CMV positif pada pasien $(p=0,228)$. Namun, pneumonia dan necrotizing enterocolitis (NEC) diketahui memiliki hubungan yang signifikan dengan IgM anti-CMV pada pasien dengan nilai $p$ berturut-turut 0,002 dan 0,034 (Tabel 2).

Manifestasi klinis pneumonia menunjukkan odds ratio sebesar 0,538 , artinya bahwa bayi baru lahir dengan pneumonia memiliki peluang $50 \%$ lebih rendah untuk menunjukkan hasil IgM anti-CMV positif dibandingkan dengan bayi baru lahir tanpa pneumonia. Sementara itu, manifestasi klinis NEC, didapatkan odds ratio sebesar 12,0, sehingga dapat disimpulkan bahwa bayi baru lahir dengan NEC 12 kali lipat lebih mungkin menunjukkan hasil IgM anti-CMV positif.

Hubungan Manifestasi Klinis dengan DNA CMV pada Saliva dan Urin Bayi Baru Lahir dengan Dugaan Infeksi CMV Kongenital

Tidak terdapat hubungan yang signifikan antara manifestasi klinis ikterus, pneumonia, dan NEC dengan DNA CMV pada saliva pasien (Tabel 3) maupun dengan DNA CMV pada urin pasien (Tabel 4).

Hubungan antara IgM Anti-CMV dengan DNA CMV pada Saliva dan Urin Bayi Baru Lahir dengan Dugaan Infeksi CMV Kongenital
Didapatkan hubungan yang signifikan $(\mathrm{p}$ $=0,001$ ) antara IgM anti-CMV dengan DNA CMV yang terdeteksi pada saliva bayi baru lahir dengan dugaan infeksi CMV kongenital, dengan odds ratio 50,0 yang berarti bayi baru lahir dengan dugaan infeksi CMV kongenital ditunjang dengan IgM anti-CMV yang positif, 50 kali lipat lebih mungkin memiliki nilai positif pada pemeriksaan DNA CMV pada spesimen saliva (Tabel 5).

Didapatkan hubungan yang signifikan ( $\mathrm{p}$ $=0,002$ ) antara lgM anti-CMV dengan DNA CMV yang terdeteksi pada sampel urin bayi baru lahir dengan dugaan infeksi CMV kongenital, dengan odds ratio sebesar 25,0, yang berarti bayi baru lahir dengan dugaan infeksi CMV ditunjang dengan nilai lgM CMV yang positif, 25 kali lipat lebih mungkin memiliki nilai positif pada pemeriksaan DNA CMV pada urin (Tabel 6).

Perbandingan Nilai Sensitivitas dan Spesifitas Pemeriksaan IgM Anti-CMV terhadap Pemeriksaan DNA CMV pada Saliva dan Urin

Sensitivitas dan spesifitas pemeriksaan menggunakan uji Mc Nemar, mendapatkan angka sensitivitas pemeriksaan IgM anti-CMV pada bayi baru lahir dengan dugaan infeksi CMV kongenital terhadap pemeriksaan DNA CMV pada saliva adalah $80,0 \%$, sedangkan spesifitasnya adalah $92,6 \%$ (Tabel 7). Angka sensitivitas pemeriksaan IgM anti-CMV pada bayi baru lahir dengan dugaan infeksi CMV kongenital terhadap pemeriksaan DNA CMV pada urin adalah $75 \%$, dan spesifitasnya adalah $89,3 \%$.

Nilai positive predictive value dan negative predictive value dari pemeriksan IgM antiCMV terhadap pemeriksaan DNA CMV pada sampel saliva adalah berturut-turut $66,7 \%$ dan 96,2\%; sedangkan nilai positive predictive value dan negative predictive value dari pemeriksan IgM CMV terhadap pemeriksaan DNA CMV pada sampel urin adalah berturutturut $50,0 \%$ dan $96,2 \%$. 
Tabel 1. Karakteristik bayi baru lahir dengan dugaan infeksi CMV kongenital

\begin{tabular}{|c|c|c|c|c|c|c|}
\hline $\begin{array}{l}\text { Karakteristik } \\
\text { Sampel }\end{array}$ & $\begin{array}{l}\text { IgM anti- } \\
\text { CMV } \\
\text { positif } \\
\mathrm{n}(\%)\end{array}$ & $\mathrm{p}$-value & $\begin{array}{l}\text { DNA CMV } \\
\text { positif } \\
\mathrm{n}(\%)\end{array}$ & $p$-value & $\begin{array}{l}\text { IgM anti-CMV } \\
\text { dan DNA } \\
\text { CMV positif } \\
\mathrm{n}(\%)\end{array}$ & $p$-value \\
\hline \multicolumn{7}{|l|}{ Jenis kelamin } \\
\hline Laki-laki & $5(83,3)$ & \multirow{2}{*}{0,446} & $4(80,0)$ & \multirow{2}{*}{0,563} & $4(100)$ & \multirow{2}{*}{0,246} \\
\hline Perempuan & $1(16,7)$ & & $1(20,0)$ & & $0(0)$ & \\
\hline \multicolumn{7}{|l|}{ Berat badan lahir } \\
\hline BBLR & $3(50,0)$ & \multirow{3}{*}{0,148} & $2(40,0)$ & \multirow{3}{*}{0,085} & $2(50,0)$ & \multirow{2}{*}{0,254} \\
\hline BBLSR & $3(50,0)$ & & $3(60,0)$ & & $2(50,0)$ & \\
\hline \multicolumn{5}{|l|}{ Usia kehamilan } & & \\
\hline Amat sangat prematur & $2(33,3)$ & \multirow{4}{*}{0,004} & $1(20,0)$ & \multirow{4}{*}{0,281} & $1(25,0)$ & \multirow{4}{*}{0,118} \\
\hline Sangat prematur & $0(0)$ & & $1(20,0)$ & & $0(0)$ & \\
\hline Late Preterm & $4(66,7)$ & & $3(60,0)$ & & $3(75,0)$ & \\
\hline Aterm & $0(0)$ & & $0(0)$ & & $0(0)$ & \\
\hline \multicolumn{7}{|l|}{ Cara persalinan } \\
\hline Sectio caesaria & $3(50,0)$ & \multirow{2}{*}{0,371} & $3(60,0)$ & \multirow{2}{*}{0,572} & $2(50,0)$ & \multirow{2}{*}{0,427} \\
\hline Normal & $3(50,0)$ & & $2(40,0)$ & & $2(50,0)$ & \\
\hline \multicolumn{7}{|l|}{ Masa kehamilan } \\
\hline SMK & $5(83,3)$ & \multirow{2}{*}{0,673} & $4(80,0)$ & \multirow{2}{*}{0,599} & $3(75,0)$ & \multirow{2}{*}{0,512} \\
\hline KMK & $1(16,7)$ & & $1(20,0)$ & & $1(25,0)$ & \\
\hline
\end{tabular}

Keterangan: $\mathrm{CMV}=$ Cytomegalovirus; BBLR $=$ Berat Badan Lahir Rendah; BBLSR $=$ Berat Badan Lahir Sangat Rendah; SMK = Sesuai Masa Kehamilan; KMK = Kecil Masa Kehamilan; *DNA CMV positif baik pada sampel saliva saja atau sampel urin saja atau pada sampel saliva dan sampel urin.

Tabel 2. Hubungan antara manifestasi klinis dengan IgM anti-CMV pada bayi baru lahir dengan dugaan infeksi CMV kongenital

\begin{tabular}{|c|c|c|c|c|c|}
\hline \multirow[b]{2}{*}{$\begin{array}{l}\text { Variabel Manifestasi } \\
\text { Klinis }\end{array}$} & \multicolumn{2}{|c|}{ IgM anti-CMV } & \multirow[b]{2}{*}{ Total } & \multirow[b]{2}{*}{$p$-value } & \multirow[b]{2}{*}{$\begin{array}{l}\text { Odds } \\
\text { Ratio }\end{array}$} \\
\hline & $\begin{array}{l}\text { Positif } \\
\mathrm{n}(\%)\end{array}$ & $\begin{array}{c}\text { Negatif } \\
\mathrm{n}(\%)\end{array}$ & & & \\
\hline \multicolumn{6}{|l|}{ Ikterus } \\
\hline Positif & $4(66,7)$ & $23(88,5)$ & 27 & 0,228 & - \\
\hline Negatif & $2(33,7)$ & $3(11,5)$ & 5 & & \\
\hline \multicolumn{6}{|l|}{ Pneumonia } \\
\hline Positif & $0(0)$ & $19(73,1)$ & 19 & 0,002 & 0,538 \\
\hline Negatif & $6(100)$ & $7(26,9)$ & 13 & & \\
\hline \multicolumn{6}{|l|}{ NEC } \\
\hline Positif & $3(50,0)$ & $2(7,7)$ & 5 & 0,034 & 12,0 \\
\hline Negatif & $3(50,0)$ & $24(92,3)$ & 27 & & \\
\hline
\end{tabular}

Keterangan: $\mathrm{NEC}=$ Necrotizing enterocolitis. Jika $p$-value $<0,05$ berarti ada perbedaan yang bermakna dan jika $p$-value $>0,05$ berarti tidak ada perbedaan yang bermakna. 
Tabel 3. Hubungan antara manifestasi klinis dengan DNA CMV pada saliva bayi baru lahir dengan dugaan infeksi CMV kongenital

\begin{tabular}{lcccc}
\hline \multirow{2}{*}{$\begin{array}{l}\text { Variabel Manifestasi } \\
\text { Klinis }\end{array}$} & \multicolumn{2}{c}{ DNA CMV Saliva } & \multirow{2}{*}{ Total } & p-value \\
\cline { 2 - 3 } Ikterus & Positif & Negatif & & \\
$\quad$ Positif & $3(60,0)$ & $24(88,9)$ & 27 & 0,163 \\
$\quad$ Negatif & $2(40,0)$ & $3(11,1)$ & 5 & \\
$\begin{array}{c}\text { Pneumonia } \\
\quad \text { Positif }\end{array}$ & $1(20,0)$ & $18(66,7)$ & 19 & 0,132 \\
$\quad$ Negatif & $4(80,0)$ & $9(33,3)$ & 13 & \\
NEC & & & & \\
$\quad$ Positif & $2(40,0)$ & $3(11,1)$ & 5 & 0,163 \\
$\quad$ Negatif & $3(60,0)$ & $24(88,9)$ & 27 & \\
\hline
\end{tabular}

Keterangan: $\mathrm{NEC}=$ Necrotizing enterocolitis. Jika $p$-value $<0,05$ berarti ada perbedaan yang bermakna dan jika $p$-value $>0,05$ berarti tidak ada perbedaan yang bermakna.

Tabel 4. Hubungan antara manifestasi klinis dengan DNA CMV pada urin bayi baru lahir dengan dugaan infeksi CMV kongenital

\begin{tabular}{lcccc}
\hline Variabel Manifestasi & \multicolumn{2}{c}{ DNA CMV Urin } & \multirow{2}{*}{ Total } & p-value \\
\cline { 2 - 3 } Klinis & Positif & Negatif & & \\
Ikterus & & & & \\
$\quad$ Positif & $2(50,0)$ & $25(89,3)$ & 27 & 0,105 \\
$\quad$ Negatif & $2(50,0)$ & $3(10,7)$ & 5 & \\
Pneumonia & & & & \\
$\quad$ Positif & $1(25,0)$ & $18(64,3)$ & 19 & 0,279 \\
$\quad$ Negatif & $3(75,0)$ & $10(35,7)$ & 13 & \\
NEC & & & & \\
$\quad$ Positif & $2(50,0)$ & $3(10,7)$ & 5 & 0,105 \\
$\quad$ Negatif & $2(50,0)$ & $25(89,3)$ & 27 & \\
\hline
\end{tabular}

Keterangan: $\mathrm{NEC}=$ Necrotizing enterocolitis. Jika $p$-value $<0,05$ berarti ada perbedaan yang bermakna dan jika $p$-value $>0,05$ berarti tidak ada perbedaan yang bermakna.

Tabel 5. Hubungan antara IgM anti-CMV dengan DNA CMV pada saliva bayi baru lahir dengan dugaan infeksi CMV kongenital

\begin{tabular}{lccccc}
\hline \multirow{2}{*}{ Variabel } & \multicolumn{2}{c}{ DNA CMV Saliva } & \multirow{2}{*}{ Total } & p-value & Odds \\
\cline { 2 - 3 } IgM anti-CMV & Positif & Negatif & & & \\
Positif & $4(80,0)$ & $2(7,4)$ & 6 & 0,001 & 50,0 \\
$\quad$ Negatif & $1(20,0)$ & $25(92,6)$ & 26 & & \\
Total & 5 & 27 & 32 & & \\
\hline
\end{tabular}

Keterangan: Jika $p$-value $<0,05$ berarti ada perbedaan yang bermakna dan jika $p$-value $>0,05$ berarti tidak ada perbedaan yang bermakna. 
Tabel 6. Hubungan antara IgM anti-CMV dengan DNA CMV pada urin bayi baru lahir dengan dugaan infeksi CMV kongenital

\begin{tabular}{cccccc}
\hline \multirow{2}{*}{$\begin{array}{c}\text { Variabel } \\
\text { IgM anti-CMV }\end{array}$} & \multicolumn{2}{c}{ DNA CMV Urin } & Total & p-value & $\begin{array}{c}\text { Odds } \\
\text { ratio }\end{array}$ \\
\cline { 2 - 3 } $\begin{array}{c}\text { Positif } \\
\text { Negatif }\end{array}$ & $3(75,0)$ & $3(10,7)$ & 6 & 0,002 & 25,0 \\
Total & $1(25,0)$ & $25(89,3)$ & 26 & & \\
\hline
\end{tabular}

Keterangan: Jika $p$-value $<0,05$ berarti ada perbedaan yang bermakna dan jika $p$-value $>0,05$ berarti tidak ada perbedaan yang bermakna.

Tabel 7. Analisis sensitivitas dan spesifitas antara pemeriksaan IgM anti-CMV dengan pemeriksaan DNA CMV pada saliva dengan uji Mc Nemar

\begin{tabular}{lcc}
\hline \multirow{2}{*}{ Variabel } & \multicolumn{2}{c}{ DNA CMV Saliva } \\
\cline { 2 - 3 } IgM anti-CMV & Positif & Negatif \\
Positif & 4 & 2 \\
Negatif & 1 & 25 \\
Total & 5 & 27 \\
\hline
\end{tabular}

Tabel 8. Analisis sensitivitas dan spesifitas antara pemeriksaan IgM anti-CMV dengan pemeriksaan DNA CMV pada urin dengan uji Mc Nemar

\begin{tabular}{ccc}
\hline Variabel & \multicolumn{2}{c}{ DNA CMV Urin } \\
\cline { 2 - 3 } IgM anti-CMV & Positif & Negatif \\
Positif & 3 & 3 \\
Negatif & 1 & 25 \\
Total & 4 & 28 \\
\hline
\end{tabular}

\section{Pembahasan}

\section{Karakteristik Penelitian}

Karakteristik dasar sampel pada penelitian ini yaitu jenis kelamin laki-laki sebanyak 23 sampel sedangkan perempuan sebanyak 9 sampel. Sebanyak 4 sampel dengan hasil DNA CMV positif berjenis kelamin laki-laki, sedangkan 1 sampel dengan jenis kelamin perempuan. Jenis kelamin mempunyai andil yang besar terhadap derajat dari berbagai macam penyakit infeksi, dimulai saat awal kehidupan. Secara keseluruhan morbiditas dan mortalitas lebih tinggi pada jenis kelamin laki-laki.
Pada penelitian ini tidak terdapat perbedaan bermakna berat badan lahir pada kelompok dengan DNA CMV negatif dengan DNA CMV positif. Hal ini sesuai dengan penelitian sebelumnya yang menyatakan bahwa berat badan lahir tidak berbeda bermakna secara statistik $(p=0,11)$ pada bayi baru lahir yang terinfeksi maupun bayi baru lahir yang tidak terinfeksi CMV.12 Namun, penelitian lain menyatakan rerata berat badan bayi yang terinfeksi CMV lebih rendah dibandingkan dengan rerata berat badan bayi yang tidak terinfeksi CMV. Hal ini disebabkan oleh adanya imaturitas sistem imun pada bayi dengan BBLR sehingga menjadi faktor predisposisi terjadinya infeksi CMV. ${ }^{13}$ 
Hasil penelitian ini menunjukkan bahwa usia kehamilan rata-rata pasien pada kelompok anak dengan lgM anti-CMV negatif dengan IgM anti-CMV positif berbeda bermakna. Hal ini sesuai dengan penelitian yang menunjukkan bahwa jumlah bayi prematur lebih tinggi secara signifikan dibandingkan dengan bayi aterm yang terinfeksi CMV dan infeksi CMV kongenital merupakan faktor risiko persalinan prematur. ${ }^{14}$ Penelitian lain menyatakan bahwa bayi yang terinfeksi CMV, 91\% merupakan bayi dengan BBLR dan $83 \%$ merupakan bayi prematur, $29 \%$ dengan KMK. ${ }^{15}$

Hubungan Manifestasi Klinis dengan IgM AntiCMV

Dari penelitian ini dilakukan analisis berbagai manifestasi klinis meliputi ikterus, pneumonia, dan NEC terkait status serologi IgM anti-CMV saja. Ikterus tidak berhubungan dengan status serologi lgM anti-CMV, meskipun ikterus merupakan manifestasi klinis tersering dari infeksi CMV kongenital hepatik. ${ }^{16}$ Ikterus juga ditemukan pada $67 \%$ dari pasien dengan infeksi CMV kongenital, ${ }^{17}$ mirip dengan hasil penelitian ini dengan angka kejadian 40$60 \%$ berdasarkan status DNA CMV pasien. Namun, tidak adanya peningkatan dan hubungan serologi lgM anti-CMV dan manifestasi ikterus dapat disebabkan oleh penyebab lain yang tidak diperiksa secara menyeluruh pada penelitian ini.

Pneumonia juga merupakan salah satu manifestasi klinis pada infeksi CMV. Pada beberapa kasus yang dilaporkan, infeksi CMV bermanifestasi pada paru-paru, terutama menimbulkan pneumonia. ${ }^{18}$ Berdasarkan nilai odds ratio, pada pneumonia justru $50 \%$ lebih tidak berisiko untuk terdeteksi IgM anti-CMV pada bayi baru lahir dengan dugaan CMV kongenital. Hal ini mungkin disebabkan karena pneumonia yang terjadi disebabkan oleh etiologi lain. Pneumonia pada neonatus berusia kurang dari 3 minggu lebih sering disebabkan karena infeksi kuman dari ibu saat persalinan.
Streptococcus grup B dan bakteri enterik gram negatif adalah patogen yang paling sering ditemukan pada neonatus dan didapatkan melalui transmisi vertikal dari ibu saat proses persalinan. ${ }^{19}$

Pada penelitian ini, NEC juga ditemukan berhubungan signifikan dengan status serologi IgM anti-CMV NEC dilaporkan memiliki prevalensi tinggi dengan infeksi CMV. ${ }^{20}$ Selain itu, pada artikel lain ditemukan kasus bahwa enterocolitis akibat infeksi CMV dapat menyerupai NEC. ${ }^{21}$

Hubungan Manifestasi Klinis dengan DNA CMV Saliva

Manifestasi klinis pada penelitian ini tidak menunjukkan adanya hubungan yang signifikan dengan DNA CMV. Hal ini juga selaras dengan temuan yang menunjukkan bahwa tidak terdapat perbedaan yang signifikan antara temuan gejala ikterus baik pada bayi dengan DNA CMV positif maupun negatif ( $p=$ 0,931).22 Hal ini dapat dijelaskan melalui temuan klinis dan laboratorium pada infeksi kongenital yang bervariasi. Selain itu, telah dijelaskan sebelumnya bahwa ikterus, pneumonia, dan NEC dapat disebabkan oleh etiologi lain.

Hubungan Manifestasi Klinis dengan DNA CMV Urin

Pada penelitian ini manifestasi klinis pneumonia, ikterus, dan NEC tidak berhubungan dengan DNA CMV yang terdeteksi pada spesimen urin bayi baru lahir dengan dugaan infeksi CMV kongenital. Hasil tersebut sama dengan penelitian sebelumnya yang dilakukan di Jepang dan Iran.

Sebuah penelitian observasional di Jepang melihat bayi yang terlihat sehat yang dideteksi keberadaan infeksi CMV dengan PCR kuantitatif menggunakan urin. Sebanyak 23.368 bayi menjadi subjek penelitian tersebut. Insiden infeksi CMV kongenital ditemukan pada sampel urin 60 bayi tersebut. 
Manifestasi yang dihubungkan adalah gangguan pendengaran sensori neural yang berbeda secara signifikan dalam hal jumlah kopi DNA antara bayi dengan gangguan tersebut dibandingkan dengan bayi yang tidak memilikinya. ${ }^{23}$

Sementara itu, penelitian di Tehran, Iran yang melibatkan 100 bayi baru lahir dengan berbagai gejala yang mengarah ke infeksi CMV kongenital menunjukkan bahwa tidak terdapat hubungan yang signifikan antara gejala klinis dan DNA CMV urin. Dalam penelitian tersebut didapatkan $55 \%$ bayi dengan gangguan pernapasan tergolong dalam kelompok DNA CMV urin positif dan sisanya negatif $(p=0,590)$, sedangkan subjek dengan ikterus hanya $45 \%$ yang memiliki DNA CMV urin positif $(p=0,655){ }^{24}$

Penelitian ini menunjukkan hasil bahwa manifestasi klinis berhubungan signifikan dengan IgM anti-CMV, namun tidak berhubungan dengan DNA CMV yang terdeteksi baik pada sampel saliva maupun urin. Hal ini dapat disebabkan karena peningkatan lgM dapat pula terjadi akibat infeksi virus lain, seperti Epstein-Barr virus, yang memiliki reaktivitas silang dengan antigen CMV. Oleh karena itu, IgM saja tidak cukup untuk menegakkan diagnosis CMV. ${ }^{24}$

Hubungan IgM Anti-CMV dengan DNA CMV pada Saliva Bayi Baru Lahir dengan Dugaan Infeksi CMV Kongenital

Pada penelitian ini ditemukan hubungan yang bermakna antara IgM anti-CMV dengan DNA CMV yang terdeteksi pada saliva dengan angka sensitivitas pemeriksaan IgM anti-CMV pada bayi baru lahir dengan dugaan infeksi CMV kongenital terhadap pemeriksaan DNA CMV pada saliva adalah $80,0 \%$, sedangkan spesifitasnya adalah $92,6 \%$.

Pada penelitian sebelumnya, status serologi lgM anti-CMV memiliki sensitivitas dan spesifisitas lebih dari $90 \%$. Hal ini lebih rendah dibandingkan DNA CMV yang diambil dari urin maupun saliva. Selain itu, tidak terdapat perbedaan yang signifikan antara pemeriksaan DNA CMV dari urin maupun saliva. ${ }^{7}$

Status serologi CMV dan status DNA CMV merupakan salah satu alat diagnostik dalam infeksi CMV. IgG anti-CMV positif seumur hidup setelah infeksi primer, sedangkan IgM anti-CMV akan positif setelah infeksi primer atau reinfeksi yang terdeteksi untuk beberapa bulan. ${ }^{25}$

Bayi dengan infeksi CMV kongenital secara persisten memiliki kadar CMV yang tinggi pada saliva dan urin. Pemeriksaan PCR dari kedua sampel ini sama akuratnya dengan pemeriksaan kultur urin. Sensitivitas dan spesifisitas dari pemeriksaan PCR saliva telah terbukti tinggi yaitu $97-100 \% .{ }^{26}$

Berdasarkan penelitian kami, maka pemeriksaan IgM anti-CMV terhadap bayi baru lahir dengan dugaan infeksi CMV kongenital dapat digunakan di rumah sakit dengan sumber daya terbatas. Pemeriksaan IgM anti-CMV dapat dikerjakan dalam waktu yang singkat dan biaya yang lebih murah dibandingkan pemeriksaan DNA CMV dengan PCR, sehingga apabila ditemukan hasil lgM anti-CMV yang positif maka pemberian anti virus bisa diberikan. Keterlambatan pemberian anti virus dapat memperparah gejala dan sekuel perkembangan dikemudian hari.

Hubungan IgM Anti-CMV dengan DNA CMV pada Urin Bayi Baru Lahir dengan Dugaan Infeksi CMV Kongenital

Pada penelitian ini diperoleh angka spesifitas IgM anti-CMV yang tinggi terhadap pemeriksaan DNA CMV dengan PCR yakni sebesar $89,3 \%$ dan sensitivitas yang lebih rendah sebesar $75 \%$. Hasil tersebut didukung oleh penelitian Ohyama yang mendapatkan nilai spesifisitas IgM anti-CMV pada serum neonatus yang tinggi, sebesar $99,3 \%$, dan sensitivitas yang lebih rendah, sebesar $84,4 \% .27$

Sebuah penelitian mengumpulkan sampel urin dan darah pada neonatus dengan kecurigaan infeksi CMV kongenital. 
Penelitian tersebut menggunakan pemeriksaan PCR dan deteksi IgM dengan menggunakan ELISA. Sensitivitas dan spesifisitas PCR terhadap kultur virus seluruhnya $100 \%$. Namun, deteksi IgM dengan ELISA, memiliki sensitivitas $63,2 \%$ dan spesifisitas $85 \% .28$ Penelitian lain menunjukkan IgM antiCMV memiliki tingkat sensitivitas yang lebih rendah (34,5\%) dibanding PCR DNA. ${ }^{25}$

Pada penelitian lain menunjukkan status serologi CMV memiliki sensitivitas dan spesifisitas lebih dari $90 \%$. Hal ini lebih rendah dibandingkan DNA CMV yang diambil dari urin maupun saliva. Selain itu, tidak terdapat perbedaan yang signifikan antara pemeriksaan DNA CMV dari urin maupun saliva. ${ }^{7}$

Seperti yang telah dijelaskan sebelumnya, bayi dengan infeksi CMV kongenital secara persisten memiliki kadar CMV yang tinggi pada saliva dan urin. Pemeriksaan PCR dari kedua sampel ini sama akuratnya dengan pemeriksaan kultur urin. ${ }^{26}$

\section{Nilai Prediktif Pemeriksaan IgM Anti-CMV terhadap Pemeriksaan DNA CMV}

Hasil penelitian menunjukkan nilai prediktif positif dan negatif dari pemeriksaan IgM anti-CMV terhadap pemeriksaan DNA CMV dengan PCR pada sampel saliva berturut-turut sebesar $66,7 \%$ dan $96,2 \%$, sedangkan nilai prediktif positif dan negatif dari pemeriksaan IgM anti-CMV terhadap pemeriksaan DNA CMV dengan PCR pada sampel urin berturutturut sebesar $50,0 \%$ dan $86,2 \%$. Hal ini menunjukkan bahwa IgM anti-CMV memiliki nilai prediktif positif yang rendah dibanding dengan pemeriksaan DNA CMV dengan PCR. Hal tersebut sesuai dengan penelitian sebelumnya yang mendapati nilai prediktif positif dan negatif pemeriksaan IgM aniti-CMV terhadap DNA CMV berturut-turut sebesar 28,6\% dan $90,91 \%{ }^{9}$

Sebuah penelitian yang menggunakan real-time PCR dari saliva cair dan kering, serta kultur cepat yang menunjukkan bahwa spesimen saliva cair memiliki sensitivitas $100 \%$ dan spesifisitas $99,9 \%$, dengan nilai prediktif positif sebesar $91,4 \%$ dan nilai prediktif negatif sebesar $100 \%$. Hal ini sedikit berbeda dengan pemeriksaan PCR dengan spesimen saliva kering yang memiliki sensitivitas $97,4 \%$; spesifisitas $99,9 \%$, nilai prediktif positif $90,2 \%$, dan nilai prediktif negatif $99,9 \% .29$

Nilai ini berbeda dengan perbandingan nilai diagnostik serologi terkait CMV. Nilai prediktif positif memiliki tingkat yang rendah jika dibandingkan dengan pemeriksaan DNA CMV. Hal ini dapat disebabkan oleh sifat pemeriksaan serologi yang high seroprevalence. Pemeriksaan serologi ini dapat berguna pada diagnosis infeksi dengan onset baru atau reaktivasi. Pada suatu literatur menunjukkan sensitivitas sebesar $63,7 \%$ dan spesifitas $99,5 \% .{ }^{30}$

Penelitian lain menunjukkan hasil yang berbeda, yang menunjukkan bahwa IgM antiCMV memiliki nilai prediksi positif yang tinggi, yakni $96,4 \%$. Nilai tersebut mungkin cukup untuk digunakan dalam proses klinis terutama pada daerah yang memiliki keterbatasan untuk pemeriksaan PCR. Namun penggunaan IgM anti-CMV saja tidak cukup karena mempertimbangkan angka kejadian negatif palsu. ${ }^{27}$

\section{Keterbatasan Penelitian}

Tidak ada data serologi maternal tentang infeksi CMV dalam penelitian ini. Dengan adanya data serologi maternal, dapat diketahui faktor risiko untuk terjadinya infeksi CMV intrauterin dan saat infeksi primer terjadi selama kehamilan atau adanya reaktivasi. ${ }^{31}$ Penelitian ini juga tidak melakukan follow-up terhadap bayi yang terinfeksi sehingga tidak didapatkan data tentang gejala sisa dari infeksi CMV antara lain gangguan perkembangan, gangguan pendengaran dan penglihatan. Selain itu, jumlah sampel yang kurang besar, diperoleh secara consecutive sampling dengan keterbatasan waktu penelitian terhadap populasi umum yang terbatas, sehingga diperlukan penelitian lebih lanjut untuk mendapatkan hasil penelitian yang lebih valid dan lebih baik. 


\section{Kesimpulan}

Didapatkan manifestasi klinis pneumonia dan NEC pada CMV kongenital memiliki hubungan dengan IgM anti-CMV, sedangkan ikterus tidak memiliki hubungan dengan IgM anti-CMV. Didapatkan manifestasi klinis CMV kongenital tidak memiliki hubungan dengan DNA CMV dari spesimen saliva ataupun urin. Didapatkan IgM anti-CMV memiliki hubungan dengan DNA CMV yang terdeteksi pada spesimen saliva dan urin bayi baru lahir dengan dugaan infeksi CMV kongenital. Didapatkan nilai sensitivitas, spesifisitas, nilai prediktif positif, dan nilai prediktif negatif yang lebih rendah pada IgM anti-CMV.

\section{Saran}

Perlu dilakukan penelitian lebih lanjut mengenai deteksi dini CMV kongenital, penelitian lanjutan dengan menambah jumlah sampel dan sekuensing genom dari CMV untuk melihat kekeluargaan dari CMV.

\section{Daftar Pustaka}

1. Society for Maternal-Fetal Medicine, Hughes BL, Bannerman CG. Diagnosis and Antenatal Management of Congenital Cytomegalovirus Infection. Am J Obstet Gynecol. 2016; 214(6):B5-B11. doi: 10.1016/j.ajog.2016.02.042.

2. van Zuylen WJ, Hamilton ST, Naing Z, Hall $B$, Shand A, Rawlinson WD. Congenital Cytomegalovirus Infection: Clinical Presentation, Epidemiology, Diagnosis and Prevention. Obstet Med. 2014; 7(4):140146.

3. Lorenzoni F, Lunardi S, Liumbruno A, Feri $G$, Madrigali V, Fiorentini E, et al. Neonatal Screening for Congenital Cytomegalovirus Infection in Preterm and Small for Gestational Age Infants. The Journal of Maternal Fetal Neonatal Medicine. 2014; 27:1589-
93.

4. Rawlinson WD, Boppana SB, Fowler KB, Kimberlin DW, Lazzarotto T, Alain S, et al. Congenital Cytomegalovirus Infection in Pregnancy and the Neonate: Consensus Recommendations for Prevention, Diagnosis, and Therapy. Lancet Infect Dis. 2017; 17(6): e177-e188.

5. Saldan A, Gabriella F, Carlo M, Nadia G, Giorgio P, Davide A. Testing for Cytomegalovirus in Pregnancy. J Clin Microbiol. 2017; 55(3): 693-702.

6. Harrison G. Current Controversies in Diagnosis, Management, and Prevention of Congenital Cytomegalovirus: Updates for the Pediatric Practitioner. Pediatrics Annals. 2015; 44:115-25.

7. Ross SA, Novak Z, Pati S, Boppana SB. Overview of the Diagnosis of Cytomegalovirus Infection. Infect Disord Drug Targets. 2011; 11(5):466-474.

8. Pinninti SG, Shannon AR, Masako S, Zdenek N, April LP, Amina A, et al. Comparison of Saliva PCR Assay versus Rapid Culture for Detection of Congenital Cytomegalovirus Infection. Pediatr Infect Dis J. 2015; 34(5): 536 - 7.

9. Bellomo MA, Andrade PD, Costa SCB, Escanhoela CAF, Vassallo GP, Tommaso $A$, et al. Cytomegalovirus Frequency in Neonatal Intrahepatic Cholestasis Determined by Serology, Histology, Immunohistochemistry and PCR. World Journal of Gastroenterology. 2009; 15:3411-16

10. Gandhoke I, Aggarwal R, Hussain SA, Pasha ST, Sethi P, Thakur S, et al. Congenital CMV Infection; Diagnosis in symptomatic infants. Indian Journal of Medical Microbiology. 2009; 27:222-5.

11. Bilavsky E, Watad S, Levy I, Linder N, Pardo J, Ben ZH, et al. Positive IgM in Congenital CMV Infection. Clin Pediatr (Phila). 2017; 56(4): 371 - 375. 
12. Santos DVV., Souza MMR., Gonçalves SHL., Cotta ACS., Melo LA.O., Andrade $\mathrm{GMQ}$ et al. Congenital Cytomegalovirus Infection in a Neonatal Intensive Care Unit in Brazil Evaluated by PCR and Association with Perinatal Aspects. Rev Inst Med trop S Paulo. 2000; 42(3): 129-132.

13. Celini FPM, Aparecida YY, Debora MP, Suely DN, Edineia VL, Celia MDG, et al. Incidence, Risk Factors, and Morbidity of Acquired Postnatal Cytomegalovirus Infection Among Preterm Infants Fed Maternal Milk in a Highly Seropositive Population. Clin Infect Dis. 2016; 63(7): 929936.

14. Orr Kl. Congenital Cytomegaloviral Infection as a Risk Factor for Preterm Birth. Proceedings in Obstetrics and Gynecology. 2013; 3(2):10.

15. Diar HA dan Velaphi S. Characteristics and Mortality Rate of Neonates with Congenital Cytomegalovirus Infection. South African Journal of Child Health. 2014; 8(4): 133-137.

16. Min CY, Joo YS, Su JJ. Characteristics and Prognosis of Hepatic Cytomegalovirus Infection in Children: 10 Years of Experience at a University Hospital in Korea. Korean J Pediatr. 2017; 60(8): 261-265.

17. Boppana SB, Ross SA, Fowler KB. Congenital Cytomegalovirus Infection: Clinical Outcome. Clin Infect Dis. 2013; 57 Suppl 4 (Suppl 4):S178-S181. doi:10.1093/cid/ cit629

18. Szczawińska-Popłonyk A, JończykPotoczna K, Ossowska L, Bręborowicz A, Bartkowska-Śniatkowska A, Wachowiak J. Cytomegalovirus Pneumonia as the first Manifestation of Severe Combined Immunodeficiency. Cent Eur J Immunol. 2014; 39(3):392-395.

19. Ostapchuk M, Roberts DM, dan Haddy R. Community-Acquired Pneumonia in Infants and Children. Am Fam Physician.
2004; 70 (5) : 899-908.

20. Omarsdottir S, Agnarsdottir M, Casper $C$, Orrego A, Vanpée M, Rahbar A, Söderberg-Nauclér $\mathrm{C}$. High Prevalence of Cytomegalovirus Infection in Surgical Intestinal Specimens from Infants with Necrotizing Enterocolitis and Spontaneous Intestinal Perforation: A Retrospective Observational Study. J Clin Virol. 2017; 93:57-64.

21. Bar-Meir M, Farrow KN, Melin-Aldana $\mathrm{H}$, Chadwick EG. Cytomegalovirus Enterocolitis Mimicking Necrotizing Enterocolitis: Case Reports and Review of the Literature. J Pediatric Infect Dis Soc. 2013; 2(1):71-5.

22. Putri ND, Wiyatno A, Dhenni R, Sriyani IY, Dwantari AK, Handyastuti S. Birth Prevalence and Characteristics of Congenital Cytomegalovirus Infection in an Urban Birth Cohort, Jakarta, Indonesia. International Journal of Infectious Diseases. 2019; 86: 31-39

23. Yamaguchi $A$, Oh-ishi $T$, Arai $T$, et al. Screening for Seemingly Healthy Newborns with Congenital Cytomegalovirus Infection by Quantitative Real-Time Polymerase Chain Reaction using Newborn Urine: an Observational Study. BMJ Open. 2017; 7:e013810.

24. Rad ME, Talayeh SS, Fariba S, Kiana S, Nader S. Prevalence of Congenital Cytomegalovirus Infection in Symptomatic Newborns under 3 Weeks in Tehran, Iran. BMC Infectious Diseases. 2017; 17:688.

25. Wang C, Dollard SC, Amin MM, Bialek SR. Cytomegalovirus IgM Seroprevalence among Women of Reproductive Age in the United States. PLoS One. 2016; 11 (3):e0151996.

26. Gantt S, Bitnun A, Renaud C, Kakkar F, Vaudry W. Diagnosis and Management of Infants with Congenital Cytomegalovirus Infection. Paediatr Child Health. 2017; 22 (2):72-74. 
27. Ohyama S, Fazumichi $F$, Sachiyo $F$, Shinya A, Mariko A, Toshihiko I. Diagnostic Value of Cytomaegalovirus IgM Antibodies at Birth in PCR- Confirmed Congenital Cytomegalovirus Infection. Int J Mol Sci. 2019; 20:3239.

28. Albanna EA, El-Latif RS, Sharaf HA, Gohar MK, Ibrahim BM. Diagnosis of Congenital Cytomegalovirus Infection in High Risk Neonates. Mediterr J Hematol Infect Dis. 2013; 5(1):e2013049.

29. Boppana SB, Ross SA, Shimamura M. Saliva Polymerase-Chain-Reaction Assay for Cytomegalovirus Screening in Newborns. N Engl J Med. 2011; 364: 21112118.

30. Kalkan IH, Dagli U. What is the Most Accurate Method for the Diagnosis of Cytomegalovirus (CMV) Enteritis or Colitis?. Turk J Gastroenterol. 2010; 21 (1): 83-86.

31. Enders G, Daiminger A, Bader U, Exter S, Enders M. Intrauterine Transmission and Clinical Outcome of 248 Pregnancies with Primary Cytomegalovirus Infection in Relation to Gestational Age. 2011; 52. 244246. 